\title{
Współczesne zasady diagnostyki zapalenia mięśnia sercowego i kardiomiopatii pozapalnej
}

\section{Current state of diagnosis of myocarditis and postinflammatory cardiomyopathy}

\author{
Tomasz Zapolski ${ }^{1}$, Anna Haratym-Zwolak ${ }^{2}$, Andrzej Wysokiński ${ }^{1}$ \\ ${ }^{1}$ Katedra i Klinika Kardiologii Uniwersytetu Medycznego w Lublinie \\ ${ }^{2}$ Centrum Kardiologii w Chełmie
}

\section{Streszczenie}

Rozpoznanie zapalenia mięśnia sercowego nadal pozostaje dużym wyzwaniem z powodu różnorodności jego manifestacji klinicznej. W 2013 roku ukazało się stanowisko Grupy Roboczej ds. Chorób Mięśnia Sercowego i Osierdzia Europejskiego Towarzystwa Kardiologicznego. Jest to porozumienie grupy ekspertów, będące propozycją dotyczącą między innymi nowych kryteriów diagnostycznych w przypadku klinicznego podejrzenia zapalenia mięśnia sercowego. Niniejszy artykuł oparto na danych zawartych w tym dokumencie. Szczegółowo omówiono w nim współczesną definicję zapalenia mięśnia sercowego, a także przedstawiono podział zapalenia mięśnia sercowego i kardiomiopatii pozapalnej, ich etiologię i patogenezę oraz objawy. Ponadto przeanalizowano testy diagnostyczne przydatne w diagnostyce tej choroby z uwzględnieniem rangi poszczególnych badań w procesie rozpoznania. Następnie szczegółowo omówiono nowe kryteria diagnostyczne zapalenia mięśnia sercowego oparte na objawach klinicznych oraz badaniach dodatkowych. W podsumowaniu przedstawiono aktualne zalecenia Grupy Roboczej ds. Chorób Mięśnia Sercowego i Osierdzia Europejskiego Towarzystwa Kardiologicznego dotyczące rozpoznawania mięśnia sercowego/pozapalnej kardiomiopatii rozstrzeniowej. Słowa kluczowe: zapalenie mięśnia sercowego, kardiomiopatia pozapalna, rozpoznawanie

(Folia Cardiologica 2015; 10, 4: 259-267)

\section{Wstęp}

Rozpowszechnienie zapalenia mięśnia sercowego jest trudne do ustalenia, ponieważ biopsja endomiokardialna, złoty standard diagnostyczny [1], jest rzadko wykonywana. Autopsja przeprowadzona u osób młodych zmarłych z powodu nagłego zgonu sercowego wykazała, że cechy zapalenia stwierdza się w 2-42\% przypadków [2, 3]. Natomiast wykonana przyżyciowo biopsja endomiokardialna u osób z kardiomiopatią zastoinową na nieznanym podłożu wykazała cechy zapalenia u 9-16\% młodych dorosłych $[4,5]$ oraz u aż 46\% dzieci [6]. Dane te sugerują duże rozpowszechnienie zapalenia mięśnia sercowego i jego konsekwencji - pozapalnej kardiomiopatii zastoinowej. Jednocześnie rzadkość i niechęć do wykonywania biopsji endomiokardialnej wskazują na celowość poszukiwania nowych, nieinwazyjnych metod badawczych w celu łatwego rozpoznania i ograniczenia stosowania metod zabiegowych do wyselekcjonowanych i uzasadnionych klinicznie sytuacji. Zagadnieniu temu poświecone jest opublikowane w 2013 roku stanowisko Grupy Roboczej ds. Chorób Mięśnia Sercowego i Osierdzia Europejskiego Towarzystwa Kardiologicznego (European Society of Cardiology Working Group on Myocardial and Pericardial Diseases) [7].

Adres do korespondencji: dr hab. n. med. Tomasz Zapolski, Katedra i Klinka Kardiologii, Uniwersytet Medyczny w Lublinie, ul. Jaczewskiego 8, 20-950 Lublin, tel. 8172442 55, faks 8172441 51, e-mail: zapolia@wp.pl 


\section{Definicja zapalenia mięśnia sercowego}

Według definicji Światowej Organizacji Zdrowia (WHO, World Health Organization) zapalenie mięśnia sercowego to zapalna choroba miokardium rozpoznawana na podstawie ustalonych kryteriów histologicznych, immunologicznych oraz immunohistochemicznych, takich jak:

- kryteria histologiczne (tzw. kryteria Dallas) przedstawione na podstawie biopsji [8]:

- naciek zapalny z limfocytów,

- degeneracja oraz martwica miocytów o podłożu nie niedokrwiennym;

- kryteria immunologiczne;

- kryteria immunohistochemiczne [1, 7]:

- nieprawidłowy naciek zapalny zdefiniowany jako równy lub większy niż 14 leukocytów/mm², w tym do 4 monocytów/mm²,

- obecność limfocytów T CD3 w liczbie równej lub większej niż $7 / \mathrm{mm}^{2}$.

Kardiomiopatia pozapalna jest zapaleniem mięśnia sercowego $z$ upośledzeniem funkcji serca [1]. Jest ona elementem patogenetycznym kardiomiopatii rozstrzeniowej z uwzględnieniem podtypów kardiomiopatii idiopatycznej, autoimmunologicznej oraz infekcyjnej. Kardiomiopatia rozstrzeniowa zaś jest klinicznym rozpoznaniem, charakteryzującym się poszerzeniem i upośledzeniem funkcji lewej komory serca (LV, left ventricle) lub obydwu komór serca, niewynikającym z przeciążenia hemodynamicznego oraz choroby niedokrwiennej serca [1,9].

\section{Podział zapalenia mięśnia sercowego i kardiomiopatii pozapalnej}

Zależnie od obrazu histopatologicznego zapalenie mięśnia sercowego można podzielić na: limfocytowe, eozynofilowe, polimorficzne, wielkokomórkowe oraz sarkoidozę serca $[2,8,10]$. European Society of Cardiology Working Group on Myocardial and Pericardial Diseases rekomenduje jednak podział zapalenia mięśnia sercowego i kardiomiopatii pozapalnej z uwzględnieniem następujących kryteriów [7]:

- wirusowe zapalenie mięśnia sercowego - histologicznie potwierdzone zapalenie mięśnia $z$ dodatnim wynikiem reakcji reakcji łańcuchowej polimerazy (PCR, polymerase chain reaction) wirusowej;

- autoimmunologiczne zapalenie mięśnia sercowego - histologicznie potwierdzone zapalenie mięśnia sercowego bez dodatniego wyniku PCR, z obecnością autoprzeciwciał sercowych w surowicy krwi lub bez ich obecności;

- wirusowe i immunologiczne zapalenie mięśnia sercowego - histologicznie potwierdzone zapalenie mięśnia sercowego z dodatnim wynikiem PCR i obecnościa przeciwciał sercowych w surowicy krwi.

\section{Etiologia}

Etiologia zapalenia mięśnia sercowego obejmuje bardzo dużą liczbę różnorodnych przyczyn. Mimo bogactwa potencjalnych źródeł i coraz częstszego ustalania czynnika sprawczego zapalenia mięśnia sercowego oraz kardiomiopatii pozapalnej, nadal wiele przypadków pozostaje bez ustalenia adekwatnego podłoża choroby. Obecnie znane przyczyny zapalenia mięśnia sercowego oraz kardiomiopatii pozapalnej uwzględniają elementy:

- infekcyjne:

- bakterie: Staphylococcus, Streptococcus, Pneumococcus, Meningococcus, Gonococcus, Salmonella, Corynebacterium diphtheriae, Haemophilus influenzae, Mycobacterium (tuberculosis), Mycoplasma pneumoniae, Brucella;

- krętki: Borrelia (choroba z Lyme), Leptospira (choroba Weila);

- grzyby: Aspergillus, Actinomyces, Blastomyces, Candida, Coccidioides, Cryptococcus, Histoplasma, Mucormycosis, Nocardia, Sporothrix;

- pierwotniaki: Trypanosoma cruzi, Toxoplasma gondii, Entamoeba, Leishmania;

- pasożyty: Trichinella spiralis, Echinococcus granuIosus, Taenia solium;

- riketsje: Coxiella burnetii (gorączka Q), R. rickettsii (gorączka plamista Gór Skalistych), R. tsutsugamushi;

- wirusy:

$\checkmark$ wirusy kwasu rybonukleinowego (RNA, ribonucleic acid): wirus Coxsackie A i B, echowirusy, wirus polio, wirus grypy A i B, wirus nabłonka oddechowego, wirus świnki, wirus odry, wirus różyczki, wirus zapalenia wątroby typu C, wirus denga, wirus żółtej gorączki, Chikungunya virus, Junin virus, wirus gorączki Lassa, wirus wścieklizny, ludzki wirus niedoboru odporności 1 (HIV-1, human immunodeficiency virus 1 );

$\checkmark$ wirusy kwasu dezoksyrybonukleinowego (DNA, deoxyribonucleic acid): adenowirus, parvowirus B19, wirus cytomegalii, ludzki wirus opryszczki typu 6, wirus Epsteina-Barr, wirus opryszczki wietrznej, wirus opryszczki pospolitej, wirus ospy, wirus krowianki;

- immunologiczne:

- alergeny:

$\checkmark$ toksyna tężcowa, szczepionki, choroba posurowicza;

$\checkmark$ leki: penicylina, cefaklor, kolchicyna, furosemid, izoniazyd, lidokaina, tetracyklina, sulfonamidy, fenytoina, fenylobutazon, metyldopa, tiazydowe leki moczopędne, amitryptylina;

- alloantygeny: odrzut przeszczepu serca; 
- autoantygeny:

- nieinfekcyjne limfocytarne, nieinfekcyjne wielkokomórkowe;

- związane z nieprawidłowościami autoimmunologicznymi lub zaburzeniami układu odpornościowego: toczeń układowy trzewny, reumatoidalne zapalenie stawów, zespół Churga-Strauss, choroba Kawasaki, zapalne choroby kości, sklerodermia, zapalenie wielomięśniowe, myasthenia gravis, cukrzyca insulinozależna, nadczynność tarczycy, sarkoidoza, ziarniniak Wegenera, reumatyczna choroba serca (gorączka reumatyczna);

- toksyczne:

- leki: amfetamina, antracyklina, kokaina, cyklofosfamid, etanol, fluorouracyl, lit, katecholaminy, interleukina 2, trastuzumab, klozapina;

- metale ciężkie: miedź, żelazo, ołów (rzadko, przeważnie przyczyna akumulacji wewnątrzmiocytarnej);
- różne: jad skorpiona, węża, ukąszenia pająka, użądlenia pszczoły lub osy, tlenek węgla, fosfor, arszenik, azydek sodowy;

- hormony: pheochromocytoma;

- witaminy: beri-beri;

- czynniki fizyczne, promieniowanie radioaktywne, porażenie prądem elektrycznym.

\section{Patogeneza}

Główną rolę w patogenezie zapalenia wirusowego i/lub autoimmunologicznego mięśnia sercowego oraz jego progresji do kardiomiopatii pozapalnej odgrywa predyspozycja genetyczna $[10,11]$. Po uszkadzającym miocyty działaniu czynnika infekcyjnego i nieinfekcyjnego dochodzi do odsłonięcia wcześniej niewidocznych dla układu autoimmunologicznego antygenów. Inicjuje to kaskadową reakcję zapalną, która przebiega w trzech fazach (ryc. 1).

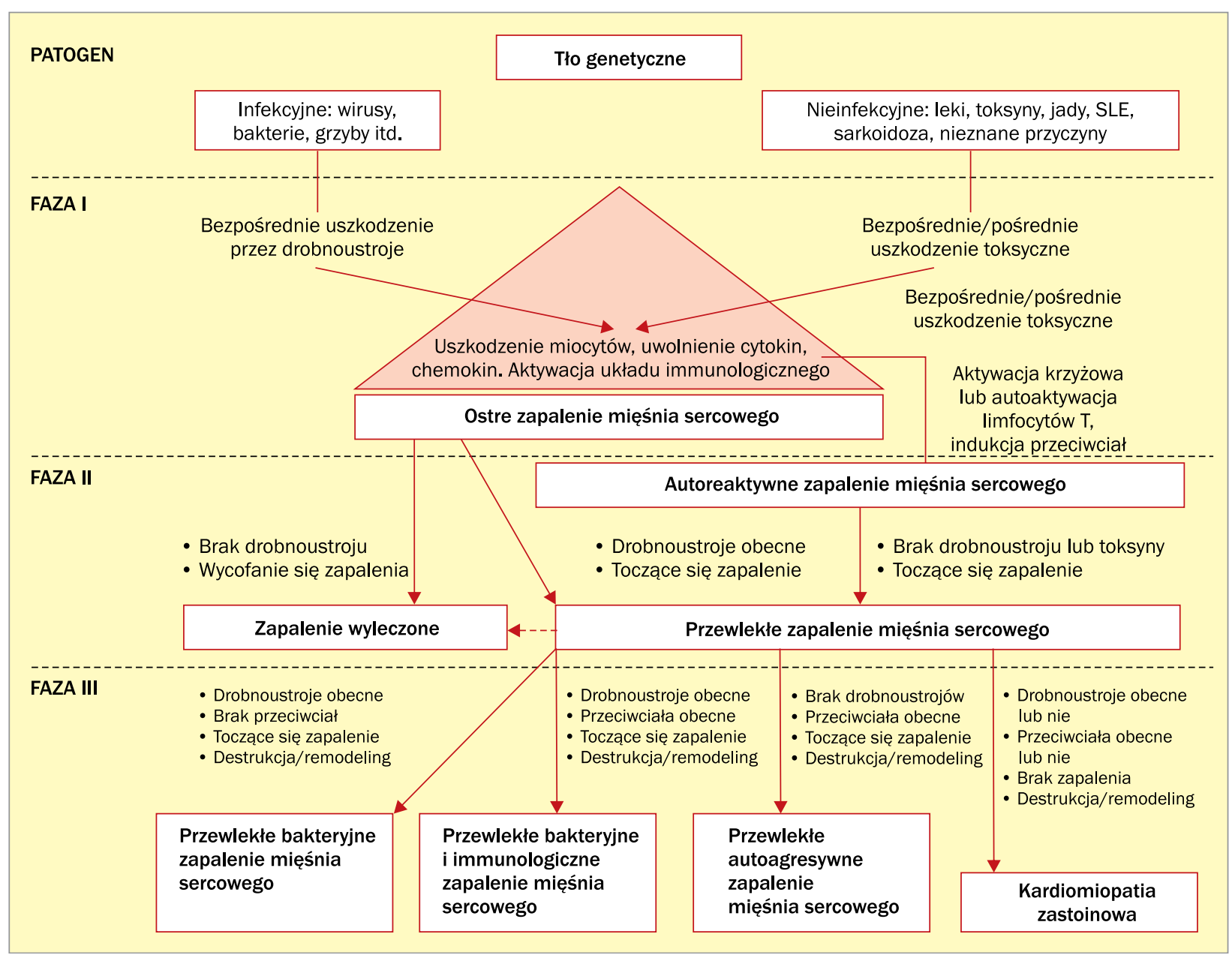

Rycina 1. Patogeneza zapalenia mięśnia sercowego oraz kardiomiopatii pozapalnej (zmodyfikowano wg [7]); SLE (systemic lupus erythematosus) - toczeń rumieniowaty układowy 


\section{Objawy kliniczne}

Przebieg kliniczny zapalenia mięśnia sercowego i związane z nim objawy kliniczne mogą być bardzo różnorodne. Zapalenie mięśnia sercowego może przebiegać w sposób podstępny, bez manifestacji klinicznej, a rozpoznanie ustalane jest dopiero na podstawie badania anatomopatologicznego. Jawne klinicznie zapalenie mięśnia sercowego może objawiać się zwiewnymi, różnorodnymi objawami o charakterze kołatania serca z przemijającymi zmianami w zapisie elektrokardiograficznym (EKG) aż do ciężkich klinicznie postaci z groźnymi zaburzeniami rytmu serca i/lub wstrząsem kardiogennym. Manifestacje kliniczne zapalenia mięśnia sercowego można usystematyzować jako czterech zespoły objawowe [7]:

1) obraz imitujący ostry zespół wieńcowy:

- ostry ból w klatce piersiowej;

- często rozpoczyna się w ciągu 1-4 tygodni od infekcji układu oddechowego lub pokarmowego;

- często związany jest z ciężkimi i nawracającymi objawami;

- brak angiograficznych zmian w tętnicach wieńcowych;

- zmiany ST/T:

- uniesienie lub obniżenie odcinka ST;

- ujemne załamki T;

- z objawami lub bez uogólnionych lub odcinkowych zaburzeń kurczliwości LV i/lub prawej komory (RV, right ventricle) $\mathrm{w}$ badaniu echokardiograficznym bądź w rezonansie magnetycznym (MRI, magnetic resonance imaging) serca;

- z objawami lub bez wzrostu stężenia troponiny T (TnT) i/lub troponiny I (Tnl), który może mieć charakter zbliżony do obserwowanego w zawale serca, ale może też utrzymywać się przez tygodnie i miesiące;

2) nowy epizod lub nasilenie objawów niewydolności krążenia w przypadku braku zmian w tętnicach wieńcowych bądź innej znanej przyczyny niewydolności serca:

- nowy epizod lub pogorszenie niewydolności krążenia w okresie od 2 tygodni do 3 miesięcy:

- duszność;

- obrzęki obwodowe;

- dyskomfort w klatce piersiowej;

- męczliwość;

- upośledzenie czynności skurczowej LV i/lub RV, ze zwiększeniem grubości ściany lub bez niego, z poszerzeniem jamy LV i/lub RV w badaniu echokardiograficznym i/lub w MRI lub bez poszerzenia;

- objawy ewentualnie zaczynają się po infekcji układu oddechowego lub pokarmowego bądź w okresie okołoporodowym;

- niespecyficzne zmiany w EKG, blok odnogi pęczka Hisa (BBB, bundle branch block), blok przedsionkowo- -komorowy (AV, atrio-ventricular) i/lub komorowe zaburzenia rytmu;

3) przewlekła niewydolność krążenia w przypadku nieobecności choroby niedokrwiennej serca i innych znanych przyczyn niewydolności serca (patrz pkt 2):

- objawy niewydolności serca (z nawracającymi zaostrzeniami) o czasie trwania dłuższym niż 3 miesiące;

- męczliwość, kołatania serca, duszność, nietypowe bóle w klatce piersiowej, zaburzenia rytmu u ambulatoryjnych pacjentów;

- upośledzenie czynności skurczowej LV i/lub RV w badaniu echokardiograficznym lub w MRI sugerujące kardiomiopatię rozstrzeniową bądź kardiomiopatię nieniedokrwienną;

- niespecyficzne zmiany w EKG, czasem BBB i/lub komorowe zaburzenia rytmu, i/lub blok AV;

4) stany zagrożenia życia, w przypadku nieobecności choroby niedokrwiennej serca i znane przyczyny niewydolności serca obejmujące:

- groźne komorowe zaburzenia rytmu serca i przebyte nagłe zatrzymanie krążenia;

- wstrząs kardiogenny;

- poważne upośledzenie czynności LV.

\section{Badania dodatkowe}

Badania pierwszego poziomu referencyjności Badanie elektrokardiograficzne

Badanie elektrokardiograficzne należy wykonać w każdym przypadku podejrzenia zapalenia mięśnia sercowego [7]. Wynik badania w przypadku zapalenia mięśnia sercowego jest zwykle nieprawidłowy, a zmiany elektrokardiograficzne mogą być zarówno specyficzne, jak i niespecyficzne. Typowe dla zapalenia mięśnia sercowego z zajęciem osierdzia są zmiany ST-T pod postacią uniesienia ST-T. W odróżnieniu od uniesienia w ostrych zespołach wieńcowych charakteryzują się one uniesieniem wklęsłym do dołu bez charakterystycznych dla zawału serca z uniesieniem odcinka ST (STEMI, ST-elevation myocardial infarction) reflektorycznych obniżek ST-T w odprowadzeniach znad ściany przeciwległej. Często widoczne jest także zawęźlenie w okolicy punktu J, tzw. pericardial knock. Blok AV może występować w każdej postaci zapalenia, jednak jego pojawienie się jest najbardziej typowe dla choroby z Lyme, sakoidozy i wielkokomórkowego zapalenia mięśnia sercowego. Zaburzenia przewodzenia AV mogą towarzyszyć także umiarkowanej rozstrzeni LV. Natomiast zaburzenia o charakterze bloków odnóg, w tym zwłaszcza bloku lewej odnogi pęczka Hisa (LBBB, left bundle branch block) są często spotykane w przypadku znacznej dysfunkcji LV, charakterystycznej dla kardiomiopatii pozapalnej. Sa one wówczas także wskaźnikiem niekorzystnego rokowania [12]. 


\section{Badanie echokardiograficzne}

Znaczenie badania echokardiograficznego z diagnostyce zapalenia mięśnia sercowego ma potrójne znaczenie. Po pierwsze pozwala na wykluczenie innych, niezapalnych przyczyn leżących u podłoża niewydolności krążenia, jak wada serca. Po drugie ocenia funkcję komór serca. Zaburzenia globalnej czynności, a także nieprawidłowości odcinkowej funkcji skurczowej są powszechnie spotykane w zapaleniu mięśnia sercowego i są stałym elementem kardiomiopatii pozapalnej. Ponadto często stwierdzane są zaburzenia czynności rozkurczowej o różnym nasileniu z upośledzeniem funkcji skurczowej lub bez niego [13]. Wreszcie badanie umożliwia nieinwazyjne monitorowanie przebiegu choroby aż do jej wyleczenia lub przeciwnie progresji do kardiomiopatii pozapalnej. Dodatkowo badanie echokardiograficzne jest dobrym narzędziem do wczesnego rozpoznawania innych, poza zaburzeniami czynności skurczowej i rozkurczowej komór, powikłań zapalenia mięśnia, jak obecność płynu w worku osierdziowym, skrzeplin w jamach serca, a także niedomykalność zastawek AV spowodowana rozstrzenią komór. Wszyscy chorzy z klinicznym podejrzeniem zapalenia mięśnia sercowego powinni mieć przy przyjęciu do szpitala wykonane przezklatkowe badanie echokardiograficzne (TTE, transthoracic echocardiography). Należy je powtórzyć w czasie hospitalizacji, jeśli doszło do pogorszenia stanu hemodynamicznego [7].

\section{Badanie scyntygraficzne}

Z wyjątkiem sarkoidozy obrazowanie izotopowe z uwagi na zmienną czułość oraz niską swoistość nie jest zalecane w diagnostyce zapalenia mięśnia sercowego [7]. Wykorzystywana w rozpoznawaniu sarkoidozy scyntygrafia talem-201 oraz technetem-99m cechuje się niską swoistością. Scyntygrafia galem-67 oraz pozytonowa tomografia emisyjna (PET, positron emission tomography) z zastosowaniem 18-fluorodeoksyglukozy są bardziej czułe i mogą być bardziej przydatne w ostrej fazie choroby oraz w monitorowaniu jej przebiegu [14-16]. Ograniczeniem jest także związana z badaniem ekspozycja na napromieniowanie.

\section{Rezonans magnetyczny serca}

Rezonans magnetyczny serca wysuwa się obecnie na pierwszy plan w nieinwazyjnej diagnostyce zapalenia mięśnia sercowego. Czas wykonania MRI zależy od Iokalnych możliwości i uwarunkowań, ale zasadą powinno być przeprowadzenie tego badania u stabilnych chorych, natomiast w przypadkach z zagrożeniem życia nie należy zwlekać z przeprowadzaniem biopsji endomiokardialnej $[7,17]$. Ocena zmian sercowo-naczyniowych w MRI powinna bazować na kryteriach z Lake-Louise (tab. 1) [18].

\section{Biomarkery}

Oznaczanie powszechnie stosowanych wskaźników stanu zapalenia, jak: odczyn Biernackiego (OB), leukocytoza, biał-
Tabela 1. Kryteria diagnostyczne dla zapalenia mięśnia sercowego w rezonansie magnetycznym (MRI, magnetic resonance imaging) (zmodyfikowano wg [18])

I. W przypadku klinicznego podejrzenia zapalenia mięśnia sercowego zmiany stwierdzone podczas MRI odpowiadają zapaleniu miokardium, jeśli spełnione są przynajmniej 2 z poniższych kryteriów:

- regionalny lub globalny wzrost intensywności sygnału miokardium w T2-zależnych obrazach odpowiadający obrzękowi

- wczesny wzrost globalnego miokardialnego współczynnika wzmocnienia gadolinium między miokardium a mięśniami szkieletowymi w T1-zależnych obrazach

- istnieje co najmniej jedno ognisko nie niedokrwiennej redystrybucji regionalnej w odwrotnych spoczynkowych wzmocnionych gadolinium T1-zależnych obrazach (późne wzmocnienie gadolinu [LGE, late gadolinium enhancement])

II. Badanie MRI odpowiada uszkodzeniu miocytów i/lub bliźnie spowodowanej zapaleniem miokardium, jeśli spełnione jest kryterium III

III. Powtórzenie badania MRI między 1. i 2. tygodniem od wyjściowego MRI jest zalecane, jeśli:

- żadne z kryteriów nie jest spełnione, ale początek objawów jest bardzo niedawny $i$ istnieją mocne kliniczne dowody zapalenia mięśnia sercowego

- spełnione jest tylko jedno kryterium

IV. Obecność dysfunkcji lewej komory lub płynu w osierdziu stanowi dodatkowy potwierdzający dowód zapalenia mięśnia sercowego

ko C-reaktywne (CRP, C-reactive protein), należy wykonać, jednak nie mają one znaczenia w rozpoznawaniu zapalenia mięśnia sercowego [7]. Konieczne jest określenie markerów sercowych: Tnl i/lub TnT oraz peptydu natriuretycznego typu B (BNP, B-type natriuretic peptide). Troponina jest wskaźnikiem uszkodzenia miocytów i jako taka stanowi także jedno z kryteriów diagnostycznych stosowanych do rozpoznawania zapalenia mięśnia sercowego. Jest to jednak tylko marker potwierdzający, a zatem prawidłowy poziom Tnl/T nie stanowi podstawy do wykluczenia zapalenia mięśnia sercowego [19]. Oznaczenie poziomu BNP daje cenne informacje dotyczące stanu układu sercowo-naczyniowego i pomaga w monitorowaniu postępów leczenia zwłaszcza w przypadkach z towarzyszącą niewydolnością krążenia [20].

Diagnostyka wirusologiczna ma ograniczone znaczenie w diagnostyce zapalenia mięśnia sercowego [21], dlatego też nie jest zalecana [7]. Dodatnie wyniki serologiczne z obecnością przeciwciał przeciwwirusowych nie są bowiem bezpośrednim dowodem na zapalenie mięśnia sercowego, lecz wskazują na kontakt układu immunologicznego z wirusami w przeszłości (przeciwciała immunoglobuliny G [IgG]) lub obecnie (przeciwciała 
immunoglobuliny M [lgM]). W wybranych sytuacjach klinicznych wirusologiczne oznaczenia serologiczne mogą mieć jednak istotne znacznie pomocnicze, między innymi: wirusowe zapalenie wątroby typu C, zakażenie riketsjami, choroba z Lyme w endemicznych rejonach jej występowania oraz przy zarażeniu zespołem nabytego niedoboru odporności (AIDS, acquired immune deficiency syndrome) u chorych z grupy wysokiego ryzyka [7]. Brak genomu wirusowego w biopsji endomiokardialnej łącznie z obecnością przeciwciał przeciwsercowych sugeruje mediowane immunologicznie zapalenie mięśnia sercowego lub kardiomiopatię pozapalną [22, 23]. Jak dotąd wykryto liczne przeciwciała przeciwko różnym strukturom serca o wielokierunkowym znaczeniu rokowniczym i potencjalnym znaczeniu terapeutycznym (tab. 2) [7, 24]. Oznaczenie przeciwciał przeciwsercowych z surowicy krwi powinno być przeprowadzane, jeśli jeden (lub więcej) z uznanych testów jest dostępny w danym ośrodku.

Tabela 2. Autoprzeciwciała sercowo-swoiste w surowicy krwi w autoimmunologicznym zapaleniu mięśnia sercowego i/lub kardiomiopatii rozstrzeniowej (zmodyfikowano wg [7])

\begin{tabular}{|c|c|c|c|}
\hline \multirow[t]{2}{*}{ Autoprzeciwciała sercowo-swoiste } & \multicolumn{2}{|c|}{ Odsetek z pozytywnymi autoprzeciwciałami } & \multirow[t]{2}{*}{ Efekt działania/znaczenie kliniczne } \\
\hline & $\begin{array}{l}\text { Zapalenie mięśnia } \\
\text { sercowego (\%) }\end{array}$ & $\begin{array}{l}\text { Kardiomiopatia } \\
\text { rozstrzeniowa (\%) }\end{array}$ & \\
\hline Mięśniowo-swoiste ASA (AFA, IFA, AMLA) & $28-59$ & $9-41$ & Miocytoliza \\
\hline Sercowo-swoiste & & & Wczesne markery sercowo-chorobowo \\
\hline $\mathrm{AHA}$ & $41-56$ & $26-30$ & $\begin{array}{l}\text { specyficzne; przewidywanie kardiomiopatii } \\
\text { rozstrzeniowej }\end{array}$ \\
\hline AIDA & 17 & 16 & \\
\hline Przeciwko receptorowi $\beta_{1}$ & $73-96$ & $27-95$ & $\begin{array}{l}\text { Negatywne predyktory, działanie proapop- } \\
\text { totyczne oraz inne efekty in vitro }\end{array}$ \\
\hline Przeciwko receptorowi $\beta_{2}$ & Nie badano & $13-75$ & $\begin{array}{l}\text { Związek z idiopatycznymi zaburzeniami } \\
\text { rytmu }\end{array}$ \\
\hline $\begin{array}{l}\text { Przeciwko receptorowi muskarynowemu } \\
\text { dla acetylocholiny }{ }_{2}\end{array}$ & 11 & $30-83$ & $\begin{array}{l}\text { Działanie inotropowo ujemne, efekty mu- } \\
\text { skarynowe, związane z przedsionkowymi } \\
\text { zaburzeniami rytmu serca }\end{array}$ \\
\hline Kardiodepersyjne (receptor Fg- $\mathrm{Y}_{2}$ ) & Nie badano & 64 & $\begin{array}{l}\text { Ujemne działanie inotropowe u szczurów } \\
\text { oraz w miocytach ludzkich in vitro }\end{array}$ \\
\hline $\begin{array}{l}\text { Przeciwko białku związanemu } \\
\text { z kanałem } \mathrm{Ky}_{2}(\mathrm{KChIP2.6-ELISA)}\end{array}$ & Nie badano & 12 & Nasilenia obumierania miocytów in vitro \\
\hline Przeciwko $\alpha$-MHC (sercowo-swoiste) & $17-37$ & $20-46$ & $\begin{array}{l}\text { Predyktory negatywne, działanie } \\
\text { proapoptotyczne }\end{array}$ \\
\hline Przeciwko $\mathrm{MLC}_{1}$ & Nie badano & $17-35$ & \\
\hline Przeciwko tropomiozynie & Nie badano & 55 & \\
\hline Przeciwko strukturom niemiofibrylarnym & Nie badano & 46 & \\
\hline Przeciwko MHC & Nie badano & 67 & \\
\hline Przeciwko aktynie & Nie badano & 71 & \\
\hline Przeciwko troponinie I i T & Nie badano & $1,7-20$ & Predyktory negatywne \\
\hline Przeciwko lamininie & 73 & 78 & \\
\hline Przeciwko HSP60,70 & Nie badano & $10-85$ & \\
\hline Przeciwko ATP-azie $\mathrm{Na}^{+} / \mathrm{K}^{+}$ & 26 & Nie badano & Predyktory komorowych zaburzeń rytmu \\
\hline Przeciwko ANT & 91 & 57 & Ujemne działanie inotropowe \\
\hline Przeciwko $\mathrm{M}_{7}$ & 13 & 31 & \\
\hline Przeciwko BCKD-E ${ }_{2}$ & 100 & 60 & \\
\hline
\end{tabular}

ASA (antisarcolemmal antibody) - przeciwciała antysarkolemmalne; AFA (antifibrillarin antibody) - przeciwciała antyfibrylarne; IFA (anti-interfibrillary antibody) - przeciwciała antyinterfibrylarne; AMLA (antimyolemmal antibody) - przeciwciała antymiolemmalne; AHA (organ-specific and partially organ-specific anti-heart antibody) - narzadowo swoiste oraz częściowo narządowo swoiste przeciwciała antysercowe; AIDA (anti-intercalated disks antibody) - przeciwciała przeciwko wstawkom międzymiocytarnym; MHC (myosin heavy chain) - łańcuch ciężki miozyny; MLC ${ }_{1}$ (light chain of myosin 1) - łańcuch lekki miozyny komorowej 1; HSP (heat shock proteins) - białka szoku termicznego; ATP-aza $\mathrm{Na}^{+} / \mathrm{K}^{+}$(sodium-potassium adenosine triphosphatase $/ \mathrm{Na}^{+} / \mathrm{K}^{+}$pump, sodium-potassium pump) - pompa sodowo-potasowa; ANT (adenine nucleotide translocator) - translokator nukleotydu adeniny; BCKD - branched chain alpha-ketoacid dehydrogenase dihydrolipoyl transacylase 


\section{Badania drugiego poziomu referencyjności Biopsja endomiokardialna}

Biopsja endomiokardialna jest uznana za złoty standard postępowania diagnostycznego w zapaleniu mięśnia sercowego w stanach zagrożenia życia [7, 25]. Jest ona niezwykle ważna nie tylko w aspekcie diagnostycznym, ale również terapeutycznym. Poza ustalaniem etiologii oraz typu zapalenia (np. sarkoidoza, wielkokomórkowe zapalenie mięśnia sercowego) pozwala bowiem na bezpieczne leczenie immunosupresyjne w przypadkach zapalenia nieinfekcyjnego, a w przypadkach wirusowego tła choroby - na adekwatne leczenie antywirusowe [24, 26]. W celu zoptymalizowania wyników i uniknięcia błędów należy ją wykonać we wczesnym okresie choroby z pobraniem wielu próbek z różnych miejsc serca [27]. Decyzję, czy biopsja ma dotyczyć RV czy LV należy podjąć na podstawie danych klinicznych wskazujących na dominujące objawy prawo- lub lewokomorowej niewydolności serca. W celu oceny w mikroskopie świetınym należny pobrać przynajmniej 3 skrawki miokardium, każdy o wielkości 1-2 mm i natychmiast zakonserwować je w 10-procentowym roztworze formaliny w temperaturze pokojowej. Dodatkowe skrawki powinny być pobrane i zamrożone w ciekłym azocie i przechowywane w temperaturze $-80^{\circ} \mathrm{C}$ lub umieszczone w probówkach RNA w temperaturze pokojowej w celu oznaczenia wirusowej PCR. Materiał tkankowy uzyskany podczas biopsji endomiokardialnej powinien być poddany analizie z zastosowaniem metod histologicznych, immunohistochemicznych oraz wirusowej PCR [7, 27, 28]. Analiza molekularna ekstraktu DNA-RNA i analiza genomu wirusa metodą PCR wydatnie zwiększa wartość diagnostyczną biopsji endomiokardialnej [23]. W celu wykluczenia infekcji systemowej konieczna jest jednak jednoczesna analiza skrawków pobranych podczas biopsji oraz próbek krwi [24, 27]. W wycinkach tkankowych pobranych w czasie biopsji endomiokardialnej, w celu zwiększenia czułości diagnostycznej badań immunohistochemicznych, gdy rozważane jest leczenie immunosupresyjne, konieczne jest stosowanie dużego panelu przeciwciał mono- i poliklonalnych do identyfikacji i oceny nacieku zapalnego oraz zwiększonej ekspresji układu ludzkich antygenów leukocytarnych (HLA-DR, human leukocyte antigen-D related) jako wykładników nieinfekcyjnego, autoimmunologicznego zapalenia mięśnia sercowego [22, 27].

\section{Zasady rozpoznawania zapalenia mięśnia sercowego (tab. 3)}

1. Kryteria kliniczne:

- ostry ból w klatce piersiowej, osierdziowy albo pseudoniedokrwienny;

- nowy epizod (dni do 3 mies.) lub pogorszenie: duszności w czasie spoczynku lub wysiłku i/lub zmęczenie z objawami lub bez objawów lewo- i/lub prawokomorowej niewydolności krążenia;
- podostre/przewlekłe (> 3 mies.) lub nasilenie duszności w czasie spoczynku lub wysiłku i/lub zmęczenie z objawami lub bez objawów lewo- i/lub prawokomorowej niewydolności krążenia;

- kołatanie serca i/lub niewyjaśniona arytmia, i/lub omdlenie, i/lub przebyte nagłe zatrzymanie krążenia;

- wstrząs kardiogenny o niejasnej przyczynie.

2. Kryteria diagnostyczne:

- zmiany stwierdzone w EKG/badaniu metodą Holtera/ /testach obciążeniowych - nowe stwierdzone nieprawidłowości w 12-odprowadzeniowym EKG i/lub metoda Holtera, i/lub testach obciążeniowych: I do III stopnia blok AV lub blok odnogi pęczka Hisa, zmiany ST-T (uniesienie ST lub bez uniesienia ST, pojawienie się ujemnych załamków T), zahamowanie zatokowe, częstoskurcz komorowy lub migotanie komór (VF, ventricular fibrillation) i asystolia, migotanie przedsionków (AF, atrial fibrillation), zmniejszenie amplitudy załamka R, wydłużenie przewodzenia śródkomorowego (poszerzenie kompleksu QRS), patologiczne załamki Q, niski woltaż, liczne pobudzenia przedwczesne, częstoskurcz nadkomorowy;

- markery uszkodzenia miocytów - podwyższenie stężeń TnT i/lub Tnl;

- czynnościowe i strukturalne nieprawidłowości w badaniach obrazowych (echo/angio/MRI) - nowe niewyjaśnione nieprawidłowości strukturalne LV i/lub PV (włączając w to incydentalne znaleziska u dotychczas bezobjawowych chorych): zaburzenia odcinkowe lub globalne czynności skurczowej bądź rozkurczowej, z pogorszeniem lub bez poszerzenia, z pogrubieniem ściany lub bez pogrubienia, z płynem w worku osierdziowym lub bez płynu, z obecnością skrzeplin wewnątrzsercowych lub bez nich;

- zmiany tkankowe rozpoznane w MRI - obrzęk i/lub obecność późnego wzmocnienia gadolinu (LGE, late gadolinium enhancement), klasycznego dla obrazu zapalenia mięśnia sercowego.

3. Potwierdzenie rozpoznania:

- jeśli występuje co najmniej jeden objaw kliniczny i co najmniej jedno kryterium diagnostyczne z różnych kategorii w przypadku obecności lub braku cech pomocniczych (patrz niżej) i w przypadku braku:

- angiograficznie potwierdzonej choroby niedokrwiennej serca (zwężenie $\geq 50 \%$ );

- znanej wcześnie choroby układu krążenia lub pozasercowej, która może wyjaśnić przyczyny zespołu (np. wada zastawkowa, wrodzona wada serca, nadczynność tarczycy); podejrzenie jest bardziej prawdopodobne w przypadku większej liczby spełnionych kryteriów;

- jeśli chory jest bezobjawowy, muszą być spełnione przynajmniej dwa kryteria diagnostyczne. 
Tabela 3. Najnowsze zalecenia dotyczące rozpoznawania zapalenia mięśnia sercowego/pozapalnej kardiomiopatii rozstrzeniowej według Grupy Roboczej ds. Chorób Mięśnia Sercowego i Osierdzia Europejskiego Towarzystwa Kardiologicznego (European Society of Cardiology Working Group on Myocardial and Pericardial Diseases) (źródło [7])

Zalecane jest wykonanie standardowego 12-odprowadzeniowego elektrokardiogramu u wszystkich chorych z klinicznym podejrzeniem zapalenia mięśnia sercowego

Wszyscy chorzy z klinicznym podejrzeniem zapalenia mięśnia sercowego powinni mieć przy przyjęciu wykonane przezklatkowe badanie echokardiograficzne

Przezklatkowe badanie echokardiograficzne powinno być powtórzone w czasie hospitalizacji, jeśli doszło do pogorszenia hemodynamicznego

Obrazowanie metodami izotopowymi nie jest rutynowo zalecane, z wyjątkiem podejrzenia sarkoidozy serca

Podstawą oceny zmian sercowo-naczyniowych w rezonansie magnetycznym powinny być kryteria z Lake-Louise

Rezonans magnetyczny serca można rozważyć przed wykonaniem biopsji endomiokardialnej u klinicznie stabilnych chorych. Rezonans magnetyczny serca nie zastępuje biopsji w rozpoznaniu zapalenia mięśnia sercowego, dlatego nie należy zwlekać z jej wykonaniem u chorych w stanie zagrożenia życia

Troponiny, OB, białko C-reaktywne powinno być oceniane u wszystkich chorych

Rutynowa wirusowa diagnostyka serologiczna nie jest zalecana

Oznaczenie przeciwciał przeciwsercowych z surowicy krwi powinno być przeprowadzane, jeśli jeden (lub więcej) z uznanych testów jest dostępny w zależności od specyfiki ośrodka. Preferowane jest oznaczanie specyficznych dla choroby przeciwciał

U wszystkich chorych z klinicznym podejrzeniem zapalenia mięśnia sercowego powinno być rozważone wykonanie koronarografii oraz biopsji endomiokardialnej

Materiał tkankowy uzyskany podczas biopsji endomiokardialnej powinien być poddany analizie z zastosowaniem metod histologicznych, immunohistochemicznych oraz wirusowej PCR (tkanki serca oraz próbki krwi)

W celu oceny w mikroskopie świetlnym należny pobrać przynajmniej 3 skrawki miokardium, każdy o wielkości 1-2 mm (z prawej lub z lewej komory), i natychmiast zakonserwować je w 10-procentowym roztworze formaliny w temperaturze pokojowej. Dodatkowe skrawki powinny być pobrane i zamrożone w ciekłym azocie i przechowywane w temperaturze $-80^{\circ} \mathrm{C}$ lub umieszczone w probówkach RNA w temperaturze pokojowej w celu oznaczenia wirusowej PCR

Biopsja endomiokardialna może być powtórzona, jeśli jest konieczna w celu monitorowania odpowiedzi na leczenie przyczynowe lub jeśli podejrzewany jest błąd oznaczenia u chorego z niewyjaśnioną progresją niewydolności krążenia

OB - odczyn Biernackiego; PCR (polymerase chain reaction) - reakcja łańcuchowej polimerazy; RNA (ribonucleic acid) - kwas rybonukleinowy

\section{Cechy pomocnicze}

Cechy pomocnicze są następujące:

- gorączka co najmniej $38^{\circ} \mathrm{C}$ w momencie przyjęcia lub w czasie 30 dni poprzedzających, z infekcją dróg oddechowych lub bez infekcji (dreszcze, bóle głowy, bóle mięśni, ogólne rozbicie) bądź przewodu pokarmowego (brak apetytu, nudności, wymioty, biegunka);

- okres okołoporodowy;

- wcześniejsze podejrzenie lub potwierdzone zapalenie mięśnia;
- osobisty i/lub rodzinny dodatni wywiad w kierunku astmy alergicznej, innych rodzajów alergii, pozasercowych chorób autoimmunologicznych, czynników toksycznych);

- kardiomiopatia rozstrzeniowa, zapalenie mięśnia sercowego w wywiadzie rodzinnym.

\section{Konflikt interesów}

Autorzy deklarują brak konfliktu interesów. 


\section{Abstract}

Diagnosis of myocarditis remains a challenge due to diversity of its clinical manifestation. A position statement of the European Society of Cardiology Working Group on Myocardial and Pericardial Diseases has been published in 2013. In this document developed by an expert consensus group, new diagnostic criteria for clinically suspected myocarditis have been proposed. The present article is based on data from this consensus statement. The article discusses in details current definitions of myocarditis. Classification of myocarditis and cardiomyopathies as well as their aetiology, pathogenesis and symptoms are also discussed. Diagnostic test for myocarditis are analysed with regard to their rank in diagnostic process. Further, diagnostic criteria for myocarditis based on clinical symptoms and diagnostic tests are thoroughly discussed. Finally, current European Society of Cardiology Working Group on Myocardial and Pericardial Diseases guidelines for diagnosis of myocarditis/postinflammatory dilated cardiomyopathy are presented.

Key words: myocarditis, postinflammatory cardiomyopathy, diagnosis

(Folia Cardiologica 2015; 10, 3: 259-267)

\section{Piśmiennictwo}

1. Richardson P., McKenna W., Bristow M. i wsp. Report of the 1995 World Health Organization/International Society and Federation of Cardiology Task Force on the Definition and Classification of cardiomyopathies. Circulation 1996; 93: 841-842.

2. Gore I., Saphir 0. Myocarditis; a classification of 1402 cases. Am. Heart J. 1947; 34: 827-830.

3. Basso C., Calabrese F., Corrado D., Thiene G. Postmortem diagnosis of sudden cardiac death victims. Cardiovasc. Res. 2001; 50: 290-300.

4. Mason J.W., O'Connell J.B., Herskowitz A. i wsp. A clinical trial of immunosuppressive therapy for myocarditis: The Myocarditis Treatment Trial Investigators. N. Engl. J. Med. 1995; 333: 269-275.

5. Felker G.M., Hu W., Hare J.W. i wsp. The spectrum of dilated cardiomyopathy. The Johns Hopkins experience in 1,278 patients. Medicine 1999; 78: 270-283.

6. Towbin J.A., Lowe A.M., Colan S.D. i wsp. Incidence, causes, and outcomes of dilated cardiomyopathy in children. JAMA 2006; 296: 1867-1876.

7. Caforio A.L., Pankuweit S., Arbustini E. i wsp. Current state of knowledge on aetiology, diagnosis, management, and therapy of myocarditis: a position statement of the European Society of Cardiology Working Group on Myocardial and Pericardial Diseases. Eur. Heart J. 2013; 34: 2636-2648.

8. Aretz H.T., Billingham M.E., Edwards W.D. i wsp. Myocarditis. A histopathologic definition and classification. Am. J. Cardiovasc. Pathol. 1987; 1: 1-10.

9. Elliott P., Andersson B., Arbustini E. i wsp. Classification of the cardiomyopathies: a position statement from the European Society of Cardiology Working Group on Myocardial and Pericardial Disease. Eur. Heart J. 2008; 29: 270-276.

10. Lim J.K., Glass W.G., McDermott D.H., Murphy P.M. CCR5: no longer a „good for nothing” gene-chemokine control of West Nile virus infection. Trends Immunol. 2006; 27: 308-312.

11. Ukena C., Mahfoud F, Kindermann I. i wsp. Prognostic electrocardiographic parameters in patients with suspected myocarditis. Eur. J. Heart Fail. 2011; 13: 398-405.

12. Maekawa Y., Ouzounian M., Opavsky M.A., Liu P.P. Connecting the missing link between dilated cardiomyopathy and viral myocarditis: virus, cytoskeleton, and innate immunity. Circulation 2007; 115: 5-8.

13. Felker G.M., Boehmer J.P., Hruban R.H. i wsp. Echocardiographic findings in fulminant and acute myocarditis. J. Am. Coll. Cardiol. 2000; 36: $227-232$.

14. Fields C.L., Ossorio M.A., Roy T.M. i wsp. Thallium-201 scintigraphy in the diagnosis and management of myocardial sarcoidosis. South Med. J. 1990; 83: 339-342.
15. Le Guludec D, Menad F, Faraggi M. I wsp. Myocardial sarcoidosis. Clinical value of technetium-99 m sestamibi tomoscintigraphy. Chest 1994; 106: 1675-1682.

16. Ohira H., Tsujino I., Yoshinaga K. ${ }^{18} \mathrm{~F}$-fluoro-2-deoxyglucose positron emission tomography in cardiac sarcoidosis. Eur. J. Nucl. Med. Mol. Imaging 2011; 38: 1773-1783.

17. Yilmaz A., Kindermann I., Kindermann M. i wsp. Comparative evaluation of left and right ventricular endomyocardial biopsy: differences in complication rate and diagnostic performance. Circulation 2010; 122: 900-909.

18. Friedrich M.G., Sechtem U., Schulz-Menger J. i wsp. Cardiovascular magnetic resonance in myocarditis: A JACC White Paper. J. Am. Coll. Cardiol. 2009; 53: 1475-1487.

19. Heymans S. Myocarditis and heart failure: need for better diagnostic, predictive, and therapeutic tools. Eur. Heart J. 2007; 28: 1279-1280.

20. Jensen J., Ma L.P., Fu M.L. i wsp. Inflammation increases NT-proBNP and the NT-proBNP/BNP ratio. Clin. Res. Cardiol. 2010; 99: 445-452.

21. Mahfoud F., Gärtner B., Kindermann M. i wsp. Virus serology in patients with suspected myocarditis: utility or futility? Eur. Heart J. 2011; 32: 897-903.

22. Maisch B., Richter A., Sandmöller A. i wsp.; BMBF-Heart Failure Network. Inflammatory dilated cardiomyopathy (DCMI). Herz 2005; 30: 535-544.

23. Dennert R., Crijns H.J., Heymans S. Acute viral myocarditis. Eur. Heart J. 2008; 29: 2073-2082.

24. Caforio A.L., Calabrese F., Angelini A. i wsp. A prospective study of biopsy-proven myocarditis: prognostic relevance of clinical and aetiopathogenetic features at diagnosis. Eur. Heart J. 2007; 28: 1326-1333.

25. Cooper L.T., Baughman K.L., Feldman A.M. i wsp. The role of endomyocardial biopsy in the management of cardiovascular disease: a scientific statement from the American Heart Association, the American College of Cardiology, and the European Society of Cardiology. Endorsed by the Heart Failure Society of American and the Heart Failure Association of the European Society of Cardiology. J. Am. Coll. Cardiol. 2007; 50: 1914-1931.

26. Kindermann I., Kindermann M., Kandolf R. i wsp. Predictors of outcome in patients with suspected myocarditis. Circulation 2008; 118: 639-648.

27. Parrillo J.E., Aretz H.T., Palacios I. i wsp. The results of transvenous endomyocardial biopsy can frequently be used to diagnose myocardial diseases in patients with idiopathic heart failure. Endomyocardial biopsies in 100 consecutive patients revealed a substantial incidence of myocarditis. Circulation 1984; 69: 93-101.

28. Leone O., Veinot J.P., Angelini A. i wsp. 2011 Consensus statement on endomyocardial biopsy from the Association for European Cardiovascular Pathology and the Society for Cardiovascular Pathology. Cardiovasc. Pathol. 2012; 21: 245-274. 